\title{
Debating Theology and the Performance of Nationhood: The Case of taqsīr al-șalāh (the Shortening of Prayer) among the Sahrawi*
}

\author{
Enrique Bengochea Tirado
}

Post-print from:

Enrique Bengochea Tirado (2020) Debating theology and the performance of nationhood: the case of taqsīr al-șalāh (the shortening of prayer) among the Sahrawi, History and Anthropology, DOI: $10.1080 / 02757206.2020 .1711750$

\section{Introduction}

In early 1977, the main fuqaha ${ }^{1}$ (legal experts in fiqh, Islamic jurisprudence) of the recently organized Sahrawi refugee camps met in the dāira of Sbetīn ${ }^{2}$ to discuss whether the population of the settlement should practice the taqsīr al-ṣalāh (the shortening/abridgement of prayers). This theological discussion was animated by the Popular Front for the Liberation of Saguia el Hamra and Rio de Oro (the Polisario Front). After the 1975 Moroccan Green March and the Moroccan and Mauritanian invasion of the territory of the former Spanish colony of the Sahara, tens of thousands of Sahrawis had fled to the open fields to escape the violence, ending up in Algerian territory. ${ }^{3}$ The Polisario Front, which was formed in 1973 and which led the anticolonial struggle against Spain until 1975, was suddenly responsible for managing an array of refugee camps inhabited by some 40,000 to 100,000 people amidst a total war (San Martin 2010, 111).

The practice of taqsìr (shortened prayer) changes the number of raka 'ät (movements) performed at each șalāh (prayer). Islam typically prescribes five șalāt every day, in a practice called tatuīl (full prayer). The first șalāh, al-șubh, is composed of two raka'āt; the second, al-ẓuhur, of four; the third, al-'așar, also of four; the fourth, al-magrib, of three; and the fifth, al-'isha, of four. In certain circumstances, the number of raka'āt in the șalāt of al-ẓuhur, al-'așar and al-'isha may be reduced to two. Both the Koran (4: 101) and the collections of hadith refer to this practice. With this said, the matter is approached differently by the * This article is part of a project that has received funding from the European Research Council (ERC) under the European Union's Horizon 2020 research and innovation programme (Grant agreement No. 716467) 1 (Plural for faquīh) Throughout the article I will follow the America Library Association-Library of Congress transliteration system.

2 Sbetīn is a site located in one of the dry river beds near the Algerian city of Tindouf. In 1975, the camps were organized by and for refugees fleeing from Western Sahara. Although the interviewees used the word "dāira", in the documents of 1976 the basic unit of settlement in the sahrawi refugee camps was the "mukhayamat" (camps), for example: Congresos populares especiales (La opinión de las masas, 13 May 1976) special number, p. 6; also was used the concept frī (Pazzanita 2006: 159); the political organization in dauāir (sing. dāira) was not seated in that times, this camp being established prior to the subsequent establishment of the current refugee camps: Rabuni, Smara, Bojador, Aaiun and Dajla. (I will use the Spanish transliterations of the names of the refugee camps as this is what is currently being used by the camps authorities.)

3 On 6 November 1975, before the International Court of Justice ruled over the Sahara and because of the risk of the Spanish government's holding a self-determination referendum, Morocco declared the Green March. More than 300,000 people, including Moroccan soldiers and civilians, entered the territory of the former colony of the Spanish Sahara, supported by Mauritanian troops in the south of the territory. Franco was dying in Spain at the time, so they decided to sign the Tripartite Agreements on November 14. These agreements established the tripartite management of the territory until February 1976, at which point Spain would withdraw to carry out the referendum of self-determination directed by Morocco. 
different schools (madāhib) of Sunni Islam, among which Maleki madhab is hegemonic in the Western Saharan region. This practice is related to situations of lower safety or travel and was part of a larger series of decisions governing rituals in refugee camps, such as fasting during Ramadan, the construction of mosques, and the duration of certain șalāt. The solutions to these problems have been multiple and have depended on theological debates within the camps on the political, social and geopolitical context in which they have been carried out for more than forty years of exile.

The abovementioned assembly established the taqsīr as the hegemonic way of practicing prayer. This decision implied the unification of religious practices for the entire population of the refugee camps mainly women, children and the elderly. The decision resulted from the application, to the religious field, of markaziyah dimuqratiah (democratic centralism), the guiding principle of political life in the camps during the first years of their formation. This form of organization seems to have been the pivotal point from which the Polisario Front applied its revolutionary program, which sought to create an egalitarian nation beyond the tribal and statutory differences that defined the precolonial social organization of Trāb albị̣̂an. ${ }^{4}$ Whereas during the 1970s and 1980s this unifying practice had been purposefully observed, this uniformity began to crumble in the 1990s. The performance of the taqsīr implied a liminal ${ }^{5}$ state of danger, instability and uncertainty that is difficult to maintain, which led to resistance. Despite its growing disuse, to this day there are people, especially the elderly, who still practice shortened prayer, associating this practice with their loyalty to the state and the Sahrawi nation.

In this article, I analyse the historical evolution of this practice and the polemics in which it has been located. From this perspective, I aim to provide arguments that contribute to the academic debate on the management of the nation and the state in the Sahrawi context. It has come to my attention that the religious dimension of this particular case is seldom addressed. I believe that attention to this aspect can shed light on the ways in which liberation projects can manage the expectations of refugee populations by framing the performative practices of revolution. In the case of the Sahrawi, a phenomenon that began in a time of "exodus" remains alive in the refugee camps to this day. In this study, which covers a period of more than forty years, I attempt to gain a better understanding of the mechanisms of nation-building, their evolution, and their adaptation.

\section{Materials and Methods}

Taking a collaborative approach (Rappaport 2008), this research was carried out jointly with the sociologist Mohammed Ali Laman from the Department of Oral Memory Collection of the Ministry of Culture, ${ }^{6}$ the

$4 \quad$ The term Trāab al-bịdān refers to the space between the river Draa in Morocco and the Senegal river from north to south, going deep into the Tindouf region and the Malian north-western Azawad. It is inhabited by a population largely constituted by nomads, mainly Hassanophones, whose social structure is based on a dynamic hierarchy built around certain qabā'il (tribes) with religious and warrior social statuses, dependent on which are tributary qaba'il and other dependent groups. More commonly, these populations are associated with the term bị̣̂an (white men), which indicates a socially elite status, and the region is by extension associated with the term Trāab al-bị̣̂ann (the land of white men) (Lopez 2003, 131-151).

$5 \quad$ This concept was introduced by Arnold Van Gennep (1960) and developed by Turner (1969, 1974). It refers to the state of exception created during change. In the beginning it was applied to rites of passage, but it was later also used to analyse revolutions. For a reflection on this concept in the Western Saharan context, see Wilson and McConnell (2015).

$6 \quad$ From this author: Laman, Mohammed Ali (2009) al-ṣaḥrā’ algharbīa: mukhtami 'ah ua zaqāfa. Rabuni: Infosolidarité. 
researcher Lahsen Selki Sidi Buna, and the anthropologist Juan Carlos Gimeno from the Autonomous University of Madrid, who put us in contact and guided the investigation in its initial stages. Professor Laman, being a great connoisseur of Sahrawi folklore and society, provided essential help with finding participants and pointing out processes of great interest to the research. Lahsen Selki not only provided indispensable support with translations, but he also was a highly engaging interlocutor without whose support I could not have understood the cultural meaning of many of the situations presented to me. Although ethnographically informed, my narrative is influenced by my background as a historian, giving importance to the chronology in order to understand some aspects of the research.

We agreed on working on the plural legal practices in the Sahrawi society. In order to do so, we arranged a set of interviews with some elder qāḍi living in the refugee camps. In the course of subsequent visits to the refugee camps, we enlarged the number of interviewees we met. ${ }^{7}$ The research on which this article is based draws on a series of in-depth interviews with a group of 45 people involved in the provision of justice from the late colonial period to the present. The average age of the participants, among which $76 \%$ were men and 24\% women, was 71 years old. The individuals resided in the six Sahrawi refugee camps around Tindouf and had different origins with regard to both - their places of birth and their tribal and family affiliations. In addition, I was given access to archives such as those at the Ministry of Information and the Ministry of Justice and Religious Affairs of the Sahrawi Arab Democratic Republic (SADR).

Each interview was prepared jointly, with Mohammed Ali doing the first round of questions in Hassaniya and myself later asking questions in Spanish, which were translated into Hassaniya by Lahsen Selki. The interviews were conducted through a biographical approach, with special attention to the interviewees' genealogy and education; activities related to the exercise of their functions; their culture and religion; and their involvement in the construction of the camps. Also, we arranged supplementary meetings with some of them in order to discuss the conclusions we were drawing and to deepen some arguments. ${ }^{8}$

During this time, I lived with Lahsen Selki's family in the cluster of homes comprising his wife's house, his sister-in-law's house, and their aunt's house in the Smara camp. This allowed me to appreciate the social depth of certain practices and issues that emerged in the interviews, taqsīr being one of them. The first interviewees indicated their participation in the abovementioned Sbetīn meeting, which took place in the initial stages of the refugee camps' organization and addressed the applicability of the taqsīr practice. At first sight, this appeared to be an anecdotal report unrelated to my investigation, which was focused on legal pluralism, but with time this topic sparked my curiosity. The discussions that took place after the interviews were especially revealing. During translation and daily work, Lahsen's friends and family would sometimes engage in heated debate. It soon become clear to me that although the shortened prayer was no longer performed by many refugees, the motivations behind it and the possibilities it opened up were of interest to my hosts. It is also true that an anthropologist is not a mere observer but a producer of social facts as well (Freire 2017, 150). During my fieldwork visits, these lively discussions took place innumerable times, indicating that this practice, although no longer explicitly commonly used, nonetheless remains implicitly relevant in a significant and controversial way. As this issue serendipitously emerged 
from my research on another topic - which is always a possibility when one assumes an anthropological perspective (Rivoal and Salazar 2013) - I decided to take an advantage of it.

\section{Tribes, Revolution and the Secular}

Sahrawi society in refugee camps is often taken as an example of what a revolutionary society should be like: an egalitarian society in which tribal practices have given way to a process of identification with the nation, where Islamic religiosity is an almost invisible, individual, private and benevolent practice (Fiddian-Qasmiyeh 2014). This discourse was mobilized by the Polisario Front in a context of exile and dependence on international aid; it is worth pointing out, however, that its success also depends on expectations of what Sahrawi society should look like. This study challenges this understanding of the Sahrawi refugee camps. Here, the management of religious practices will be considered part of a revolutionary process involving practices that combine the Marxist-Leninist tradition with those of hassanophone society.

I accept, provincializing Western modernity (Salvatore 2007), the existence of multiple modernities (Eisenstand 2000) that allow for the definition of a sphere of action framed within the nation. In this analysis, I will try to connect the agency of the liberation movement to the theological phenomenon. The Polisario Front's program has been described as "secular", but this should be understood as a broad term covering many situations and as potentially including religious management (Asad 2003). On the other hand, religious discourse should be "desacralized" in order to lay bare the historical and social contexts in which it is performed (Ennaji 2013). As Itzea Goikolea (forthcoming) points out, this desacralization implies not that religious phenomena are irrelevant to society in general, and to Arabo-Islamic societies in particular, but quite the opposite: "it is so important that it tarnishes everything because many relations, dynamics and institutions are gestated in a religious framework". ${ }^{9}$

Religiosity in Sahrawi society is an under-studied topic. Fiddian Qasmiyeh (2011) highlights the strategic dimension of the use of religious frameworks by the Polisario Front, mobilizing notions of "secularism" and "religious tolerance". In this regard, she points out that this strategy can explain the view that there are no mosques in the camps. In addition, religion is not expected to be present in such a revolutionary place. The only reference to the debate on taqsīr in refugee camps that I have been able to locate places it in the dangerous situation of dealing with Islam: “Although nomadic Islam is not a sophisticated theology, it is an Islam that is simple, rocky, without ceremonies or clergy, without mosques or madrasas, practical and adapted to the environment; the Polisario's intrusion into an especially sensitive land was more than many people could bear" (García 2001, 241-242). In this regard, the discourse on the refugee camps always tries to emphasize the secularism of its management or the "good Islam" practiced by its inhabitants. Avoiding discussion of religiosity places it on suspicious terrain.

The relationship between the $q a b \bar{a}^{\prime} i l,{ }^{10}$ the nation and the state is an important topic in anthropology. Gellner's already classic works on Muslim society (1981) and on nations and nationalism (1983) implied

$9 \quad$ For more on how religious knowledge is embodied and disputed in the wider region, see (Brenner 2001 and Ware III 2014).

10 Henceforth, I prefer to use the concept qabīlah (pl. qabā'il) when referring to the tribal structures of the region, seeking to avoid the symbolic and pejorative burden of the concept of a "tribe". 
the possibilities of group solidarity with regard to the ability of nomadic populations to transform themselves into nations. The accretion processes that took place within the Saharan qabä'il were carefully studied by the anthropologist Pierre Bonte, whose works on segmental organization in the southern region of the Sahara are of great importance (1979 and 1982). In these studies, Bonte revealed different strategic processes in which segments were fused. Historically, the qabīlah was the dominant identity space in the region (Caratini 1989; Lopez 2003). This was the case in the work carried out by the Spanish anthropologist Caro Baroja (1954) in the mid-1950s. Currently, however, spaces of sovereignty are defined in terms of nationhood (Bonte 2017).

More recently, the anthropologist Konstantina Isidoros has argued that a nomadic society's own dynamic of accretion can give rise endogenously to a national framework (Isidoros 2018). ${ }^{11}$ She has proposed that the refugee camps around Tindouf function in a deep sense as a great friq, or nomadic encampment. This vision receives a more nuanced treatment in the analysis proposed by the anthropologist Alice Wilson (2016), who describes the processes of social change produced in the refugee camps by invoking the image of a palimpsest. Just as the meaning of the faintly legible remains on certain reused parchments is preserved on the page, in Wilson's analysis the revolution carried out in the camps by the Polisario Front-SADR was transcribed over qabā'il society in a way that made it possible, following the palimpsest analogy, to decipher the practices of the qabā'il that lie beneath national practices.

Historian Pablo San Martin (2010), also working with historical documentation, reveals how the liberation movements of the 1970s strongly influenced the young leaders of the Polisario Front. In addition, he reveals the influence of these movements on the anticolonial mobilization of the past decades, as well as the adoption of practices present in the bị̣̂an repertory of contention (Tarrow 2011: 39). As the political scientist Jacob Mundy (2007) reminds us, the war is what precipitated the hurried application of a national program to a population who had relocated there for what they thought would be a few months.

Parallel to other liberation movements of the time, the Polisario Front was born within a strong anti-tribal discourse. The movement led a revolutionary process that aimed to create a more egalitarian society and nation state (Gimeno 2007). The anthropologist Sophie Caratini, who did her doctoral fieldwork in the mid1970s and who went to the refugee camps in the 1990s, points out the effects of the revolution on the structure of Sahrawi society (2003). Although she also describes important continuities, she identifies the important role of state action when it came to reorganizing Sahrawi society. This, however, is not at odds with the (pre)existence of a tribal, Muslim society.

\section{From Spanish Colonialism to the Refugee Camps}

Included in the list of Non-Self-Governing Territories subject to decolonization as of $1963,{ }^{12}$ in the mid1960s Spanish Sahara was the last remaining colony in the Western Saharan region. Facing growing international pressure to decolonize the territory after the Ifni-Sahara War (1957-1958), Franco’s Spain intensified its colonization of the territory. The region was declared a metropolitan province, border control was strengthened, and a series of investments were carried out to improve the colony's economic performance. Accompanying these policies, in a context of geopolitical and economic change resulting $11 \quad$ For a comparative perspective, see (Bonte, Conte and Dresch 2001).

12 https://www.un.org/es/decolonization/nonselfgovterritories.shtml. 
from the fragmentation of the territory, clashes among the new postcolonial states, and a series of droughts in the 1960s and 1970s, the Bedouin population slowly moved to urban centres (Bengochea and Correale forthcomming). While it is true that we cannot speak of sedentarization in this context - sedentarization being, as Isidoros (2018) argues, a strategy typical of nomadic societies - we must not underestimate the significance of the social changes in this period for what happened next.

This late Spanish colonial period can be viewed as a singular phenomenon. Although this phase was short, most of the protagonists who dominate the current political landscape were born after 1958. The 1974 census recorded 7,397 people, 60,246 of whom were recorded as sedentary and 12,428 as nomads. 35,909 of these were above 17 years of age, and 37,588 were minors. ${ }^{13}$ For more than half of the Sahara colony's population, their life experience had taken place after the region had become a province. Although the census was effectively biased, it revealed a context of cultural adaptation to the borders and a move to the city - a dynamic that occurred in a similar way in the Spanish Sahara, in the Tarfaya region, and in certain parts of Mauritania (Norris 1964). In this sense, the traditional stratified society described by Caro Baroja (1955) intersected with the challenges of colonization.

In this context, the Polisario Front was born within an anticolonial discourse that combined elements of the liberation fronts with forms of mobilization typical of bidān society. Its founding members came from a wide diaspora: the Tarfaya strip, between the Drā river and the Spanish colony; the Spanish colony itself; and the southwest of Algeria and the north of Mauritania. The birth of the Polisario mobilized people on all sides of the colonial frontier. All of these areas are home to hassanophone populations and to armed resistance against Spanish colonization. Politically, different influences participated in the founding of this organization: the exiles of the Hatarrambla demonstration, ${ }^{14}$ who were in Mauritania at the time and had contact with the National Democratic Movement (Diego Aguirre 1988); ${ }^{15}$ ex-combatants of the 1958 Liberation Army, ${ }^{16}$ resident in Tarfaya; and young university students with contacts with Moroccan Marxist-Leninist parties, such as El Uali Mustafa Sayed, founder of the Polisario (San Martin 2010, 8286).

Although the Polisario Front has never identified itself as Marxist, it was strongly inspired by liberation fronts such as the Palestinian PFLP (Allan 2010). The influence of Gaddafi's revolutionary Libya should also be noted and would later be reflected in the organization of the refugee camps (Wilson 2016). Finally, the influence of Arabist and Third World nationalist rhetoric is also worth mentioning. This did not prevent the formation of anticolonial mobilization from the historically inherited structures and organization of the biḍān space. As San Martin (2010) points out, the Uali fathers themselves, of warrior status, fought in the

13 Gobierno General del Sahara: Censo de Población, El Aaiun: Editorial Graficas Saharianas, 1975. 14 On 17 June 1970, a demonstration organized by the Sahrawi nationalist movement Harakat Tahrir took place in the neighbourhood of Jatarrambla (Zemla), in El Aaiun. This was repressed by the Spanish legion military forces, leaving many dead, wounded and missing. As a consequence of Spanish repression, many of the militants in that group went into exile in Zuerat (Mauritania). For more information on this organization, see Bárbulo (2002, 73-96) and San Martin (2010, 74-82).

15 A Marxist movement born in 1968 from the MIFERMA strikes. More information on these strikes and the social movements in Bennoune (1978).

16 The Moroccan Liberation Army (Yeish Tahrir) led the 1957-1958 anticolonial struggle. Its members had an ambiguous relationship with Sahrawi nationalism, as Correale and López (2017) show in their analysis of the "Rashomon effect". 
Ifni-Sahara War, when the organizational spaces of the anticolonial movement were broader than the colonial frontiers.

In 1972, during the mughar of Tan Tan, a first demonstration was organized. It was an annual market of regional importance, a meeting space in the hassanophone universe. This demonstration was violently repressed by Morocco. On 10 May 1973, armed action against Spanish colonization was initiated, involving the harassment of military posts at a base located in Tindouf, behind the Algerian border. In parallel, agitation inside the colony grew (Allan 2019), and the support of neighbouring countries was sought (which was met with distrust by Morocco). Tindouf was a traditional transit zone for some Sahrawi $q a b \bar{a}$ 'il, among whom they found support. In this sense, it is interesting to note that these young partisans practiced taqsīr, since they considered themselves at war and waiting to return to their territory. Conversely, those who supported them from the qaba'il of the area did not shorten their prayers, since they viewed themselves as operating in their own territory. ${ }^{17}$

In 1975, after the Green March, a large portion of the population of the Sahara fled their homes. It has been estimated that around $45 \%$ of the population of the then Spanish province escaped to the open fields, the badīah. From October 1975, small temporary camps were formed throughout the territory in Guelta, Tifariti, Um Draiga and other places. However, the violence of the Moroccan bombings (which dropped napalm on Um Draiga) forced the population to seek refuge outside their borders. Thus, little by little, many people arrived at the refugee camps that were forming in Tindouf, around the Polisario base. At the time, it was expected that the camps would be an interim solution and that the population would soon return to their homes (San Martin 2010, 113). From the beginning until the summer of 1976, the camps were organized with an almost total lack of means and humanitarian aid.

In November 1975, the shuyūkh (leaders of the qabä'il) participants of the institution of the Yemaa present in the territory of the Sahara signed the Proclamation of Guelta. ${ }^{18}$ This declaration dissolved the colonial assembly, recognizing the Polisario Front's authority in favour of a solution based on "national unity". The anthropologist Sophie Caratini $(2003,129)$ interprets this as a revolutionary gesture by which the "elder brothers", who held authority in the universe of the qabīlah, yielded it to their "younger brothers", the young activists of the Polisario Front. National unity was a concept that emerged from the third congress of the Polisario Front, held on 12 October 1975 in the vicinity of Ain Ben Tili. It acknowledged the need to eliminate social divisions, blood inequalities (inequalities within family structures) and range inequalities (inequalities among the qabā'il and the tributaries), which were the product of differences in lineage, gender, generation and status. At the time, the Polisario Front assumed not only the anticolonial struggle but also the management of the then-forming camps and the leadership of society.

$17 \quad$ Interviewees 31 and 35.

18 The Yemaa, or General Assembly of the Sahara, was presented as the representative organ of the Sahrawi population of the Spanish Sahara province. Established in May 1967, it was inspired by the assemblies that were held at the level of qabā'il to settle disputes, the jamā'at. It was formed by members who were elected according to quotas every four years within the different qabā'il. In addition, there were non-elected members as a shuyūkh of each qabā'il or fraction, as well as the president of the cabildo and the mayors of Villa Cisneros and El Aaiun. Its function was mainly consultative, acting as an intermediary between the legislation promulgated by the General Government and the Sahrawi population. At the time the declaration of Guelta was signed (28 November 1975), 67 of the 102 shuyūkh had signed it. More information in Barona (2009). 
This was a powerful and symbolic act, the result of an exceptional situation. By mid-1976, nomadization had come to a complete halt in Western Sahara, with the society divided between refugee camps and militarized cities. According to an IFHR report from 1979 (cited in Mercer [1979, 18]), in October 1976 there were 22 refugee camps in the vicinity of Tindouf, the largest of which housed 7,800 inhabitants in 660 tents. Of these, $80 \%$ were women and children, and only $10 \%$ of the tents were traditional Sahrawi tents (khayām). The Red Crescent was busy accommodating those who were arriving and improvising the initial infrastructure of the Sahrawi State. Although it had to adapt to novel circumstantial events, the construction of the camps did not arise in a discursive vacuum but was heir to the nomadic practices of the population.

A nascent legal system was formed in the camps from the very beginning, the most important members of which were participants in the colonial legal and educational system. ${ }^{19}$ They were people who belonged to $q a b \bar{a}$ 'il of prestige in the field of religion. ${ }^{20}$ Although it was covered by the Polisario Front, this legal system was only loosely controlled by it. They were in charge mainly of resolving conflicts through the practice of sulh. ${ }^{21}$ In addition, they were consulted on doctrinal subjects of Islamic practice. Many people were arriving in the refugee camps, and it was not known how long they would stay. In this context, the first consultations regarding shortened prayers took place.

In this regard, a first meeting was held. Participants included several prestigious quḍāt who were in charge during Spanish colonization and others who belonged to a lineage of Mauritanian origin but who had lived in the Tindouf region for years. A key figure in this meeting and those that followed was Saad Bu, a qaạdī closely linked to the organization of the Polisario Front. In the meeting, attended by several assistants, the quḍāt delegated decisions on political direction to Uali Mustafa Sayed, founder of the Polisario Front and then president of the SADR, who left the question to them. At the time, they decided that prayer should be performed in the usual way insofar as they were in a safe place; according to the assistants, however, this was not an official decision. ${ }^{22}$

At this early stage, there was tension between the political leadership, represented by Uali Mustafa Sayed, and Saharawi society, represented by the quḍat, with Saad Bu as an intermediary. When a meeting of the most important quḍāt in the camp was held, a community was defined: a qabā'il uniting people of different origins in the form of a nation (Isidoros 2015). This community in turn recognized the Polisario Front as its political leadership. At this point, the very nature of the camps was still under discussion. Would the camps be temporary? The fact that they were safe spaces meant that they were, according to nomadic logic, indeed temporary. However, the course of events seemed to point to a different path. On 9 June 1976, El Uali Mustafa Sayed died, and there was no sign of an end to the anticolonial war. At the end of the summer, humanitarian aid was arriving at the camps, which began to be understood as spaces of political experimentation. From that moment, the camps became spaces not only of refuge but of putting into practice a political program that would define a future independent Sahara.

\section{$19 \quad$ Interviewees 1 and 2.}

20 The tribal affiliations of those living in the refugee camps is a politically controversial issue. People were reluctant to mention their own qabīlah, especially in the presence of researchers. I have decided to respect this fact, and thus in the present text I will not touch on the qabā'il or fractions of origin of those with whom I met. For more on this, see (Wilson 2018, 183-235).

21 A legal practice defined as an amicable arrangement between parties, according to common sense (Charre 1966, 345).

22 Interviewee 2. 


\section{The Sbetīn Meeting}

Uali Mustafa Sayed's death in an attack on the Mauritanian capital left an important symbolic vacuum in the revolutionary movement. Following his death, a phase of military offensive was proclaimed, in which the People's Liberation Army ${ }^{23}$ redoubled their efforts. ${ }^{24}$ This time also marked the celebration of the third congress of the Polisario Front, held between 26 and 30 August that same year. This congress was the first to have a national character, with representatives from the Polisario Front, the state, and shuyūkh. ${ }^{25}$ In addition, the first constitution of the SADR was proclaimed. At the same time, it was clear that the war was far from over, and thus the ranks closed around the "revolutionary vanguard" under the framework of national unity. ${ }^{26}$ It should be noted that, following the logic of the offensive, the slogan for this congress was "No stability, nor peace, until our return to the national territory and total independence". ${ }^{27}$

In this context, the refugee camps were the basis for the formation of a future society based on a Sahrawi national identity and under the umbrella of the SADR (Mundy 2007). This process required an effort framed in a political program similar to that of other contemporary liberation movements. The political language of the time was strongly influenced by Muammar Gaddafi's revolutionary Libya (Wilson 2016, 13) and by prevailing notions from the Marxist-Leninist left, such as democratic centralism, or “markaziyah dimuqratiah" (San Martin 2010, 571). The latter governed the logic of decision-making, placing the authority of the party, the Polisario Front, over the civil organizational authority of the camps. This highly hierarchical principle prioritized decision-making in a nucleus of representatives and discipline within the party, subordinating minority options to majority ones. ${ }^{28}$

According to testimony, it was the construction of permanent infrastructure in the camps that unleashed new discussion about the appropriateness of shortening prayers. This construction had serious implications for the permanence of the camps. Revolutionary publications at the time expressed concerns about the increased normalization of the camps: "Currently, most of us live in camps, outside the homeland; we must not forget this provisional situation and that our presence here is also provisional". ${ }^{29}$ Certain leaders linked to the Polisario Front were concerned with taqsīr due to the need to maintain revolutionary tension. At this moment, the figure of the qāḍi Saad Bu reappears as a link between the political leadership and the fuqahā.

Despite the political motivation for raising this debate, its consequences are worthy of note. Making this decision implies deep theological reflection on the circumstances in the camps. The actors involved in the operation were aware of the transcendence of religious praxis. In that sense, it should be noted that one of the protagonists of several of the narrations was Brahim Ghali (currently President of the SADR and General Secretary of the Polisario Front), then one of the young leaders of the revolutionary movement. His

23 The People's Liberation Army was the armed wing of the Polisario Front, acting as the national army of the SADR.

24 Editorial (La opinión de las masas, 12 julio 1976), № 9, p. 1.

25 El Frente Polisario inicia su III Congreso el martes (El Pais 22 agosto 1976), recuperado de: https://elpais.com/diario/1976/08/22/internacional/209512813 850215.html.

26 Troisième Congrès du Front Polisario (26 au 30 août 1976). (1976). [Booklet] SADR Information Ministry Archives, Rabouni.

27 Idem.

28 La organización es el arma secreta del pueblo (La opinión de las masas, 28 mayo 1976) № 8, p. 6.

29 La Revolución: Vida y método (La opinión de las masas, 19 abril 1976) № 6. Traducción del

Español. 
father was a prestigious qạ̄̂̄ who was committed to practicing taqsīr and who continued to do so until his death.

Thus, at the beginning of 1977, a broad meeting was held in the dāira of Sbetīn, attended by the main fuqahā in the refugee camps. This assembly came to represent the plurality of origins of the refugees who met in the camps. The topic of discussion was whether to practice taqsīr prayer or full prayer in the refugee camps. It was an intense debate that concluded in the defeat of the position in favour of practicing shortened prayers, which had been defended by the Polisario Front. Although it was described as a matter of consensus, not all attendees agreed with the decision. Following the strict discipline of democratic centralism, the decision of the majority was imposed on the minority.

Commissions to communicate the decision were created, which were met with some resistance in fulfilling their duty. In the first place, the large camps that are present today were still to be established at the time, such that many of the dauāir were occupied by individuals linked to a single qabīlah. This happened in Sbetīn itself, the population of which consisted mainly of members of one of the qabä'il that had settled around Tindouf for some time. On this site, the assembly's decision was not well received. They prayed as usual because the refugee camps were where they had always been found. ${ }^{30}$ It is worth noting the different experiences of the inhabitants of the camps. Some came from urban contexts, located both within and outside of Western Sahara itself, for whom the camps were an exceptional, temporary place. For others, life in the camps followed the Bedouin norm as a part of a movement that would take them to Western Sahara.

Secondly, the logic of this decision-making was contrary to the way in which religious authority had been negotiated up to that point. The diversity of opinions and competition among scholars was one of the characteristics of Islam in Western Sahara (Ould al-Bara 2000). However, the new situation of revolutionary nation- and state-building required scholars to participate in the creation of community through agreement, despite their particular views. Many of the fuqahā were against taqsīr and prayed as usual in private. Despite this, they had to communicate their decision as a community:

It was political decision-making because we were living in an extraordinary situation. We are refugees, and there should be no room for differences. Therefore, the people accepted taqsir $r$, and they kept quiet to maintain the unity of the people and also because they thought it was necessary to go down that road. And my shaykh (RIP) told me: I have chosen not to break the unity of the group (djamaa), but I have not practiced taqsīr, and I have not stopped fasting in Ramadan. ${ }^{31}$

This practice was debated in the popular committees of justice. ${ }^{32}$ Several of the interviews with women participants indicated this as a point of conflict. ${ }^{33}$ At this level, the conflict was between whether religious practice should be considered an individual mater or whether it was dependent on the collective decisions

$30 \quad$ Interviewees 2 and 34.

31 Interviewee 28, translated from Hassaniya.

32 Inspired by Gaddafi's Libyan practices, the population of the refugee camps, composed mainly of women, was organized into popular committees: health, childcare, justice, supply, production and crafts. In the justice committees, women were dedicated to solving issues of justice related to the sulh and to practical matters such as the organization of weddings and funerals. In addition, a qāộ̄ was in charge of doctrinal discussions.

33 Interviewee 9. 
made through the party. Several of the interviewees point out that there was pressure to practice taqsirr, fearing that they would be reported if they prayed full-length prayers in public. ${ }^{34}$ Taqsīr was the accepted public practice, carried out in public festivities and public spaces, such as schools.

The standardization of taqsīr was embedded within a series of practices meant to establish the refugee camps as egalitarian spaces of identification with the nation. Little by little, these scattered camps were reorganized into three large camps. They were designated the main urban centres of Western Sahara: Smara, El Aaiun and Dajla. These camps, made up of rows of equal tents, were organized in dauāir, where people of different tribal and statutory origins lived together. Participation in frequent festivities and anniversaries linked to the developing war, the creation of public services as a concrete manifestation of the state, the sublimation of dowries, prohibition of the use of the genealogies and names of the qabā'il, and even cooking the same food in each administrative unit were strategies through which this unit was built (Caratini 2000; Wilson 2016).

The revolution sought to base itself not only on the idea of the nation but also on the idea of the equality of its members. Special emphasis was placed on uniformity in the political ideology of the Polisario Front. This can be understood as a strategy to abolish the symbolic reproduction of inequalities between different statuses and qabā'il. The result can be seen, paradoxically, as a form of aggregation of tribal structures, the nation being a possible product of the tribal logics themselves (Isidoros 2016). Qabā'il can deploy a whole series of aggregation strategies such as milk kinship and incorporation through genealogy (Bonte 1979, 1982). Encouraged through participation in the structures of the state and creating a new genealogy, these practices sought to integrate all qabā'il and statuses.

Wilson points out that the camps became the first place in which the Sahrawis themselves decided to move the locus of sovereignty from the qabā'il to the nation $(2016,113)$. In this sense, it is worth pointing out the performative dimension of this shift. A nation is made up of elements that are equally related to it. In addition, the apparatus of the qabīlah is maintained with different qabā'il, different degrees of kinship and different statuses and forms of dependence. This difference is reproduced through narrative and practice, repeating genealogies. As Isidoros argues, the qabā'il union was forged politically through democratic centralism (229). As a form of decision-making, democratic centralism implied centralized political control. It faced a form of traditional authority that was dispersed and segmentary and that allowed for centripetal cohesion through centripetal practices.

With regard to the decision to hold this meeting and the form it was to take, it is worth mentioning the tension between the structures of the party (the Polisario Front) and the state (the SADR). These are two entities with sometimes divergent agendas and interests, one of these being social revolution. While it is true, as Isidoros points out, that refugee camps can respond to accretion practices typical of Bedouin society and their ability to adapt, the political agency of the liberation movement should not be overlooked. As a narrative, it eliminated inequalities and performed the national community. It allowed the Polisario Front to control the means of reproduction of inequality, that is, the genealogical narrative. They effectively merged the logics of Marxist-Leninism with the theological logics of the ifta ${ }^{\prime}$ (the act of issuing fatwas). In this sense, if the national framework and certain religious practices were effective instruments for creating 
equality, this was because, to a certain extent, they were responding to the decision-making logic of Sahrawi society.

The practice of taqsīr is an element that both implies and generates liminality. The decision to practice shortened prayers came from a mechanism of democratic centralism that was applied to the religious field. In this sense, the Sbetīn assembly tried to overcome the traditional dispersed authority by imposing consensus. For years, this practice was imposed in public, creating an egalitarian community in the context of a national community. At the time, and until the beginning of the 1990s, refugee camps were mainly inhabited by women, children and the elderly. Most of the men were at the front, stationed in the contested territory of Western Sahara, fighting first against Morocco and Mauritania and then, from 1979, against Morocco alone. On the battlefront, the identification with the nation was evident. Those who died did so for the nation, and the framework of the national army was formed on the basis of guerrillas who favoured egalitarianism. In the army, each man voted according to his military constituency, and his participation in the movement or the state was not in doubt.

The situation was different in the camps, however. Those who inhabited them, the great majority of whom were women, were members of popular committees through which political life in the camps was organized. Solidarity was sought within these committees, not within the qabā'il, which the nation state sought to replace. Since the founding of the Polisario, women have participated in the anticolonial struggle (Medina 2014), with the figure of the munadila (Solana 2017), a child in one arm and a machine gun in the other, serving as a mobilizing force. Women participated symbolically in the war effort that took place at the front not only through military exercises but also thanks to taqsìr, which moved the context of the front to the rearguard.

This same logic operated in the non-observance of the Ramadan fast. Both were justified by the need to participate in a sustained war effort, allowing the women who lived in the refugee camps to act in a way that was continuous with their male companions. As far as religious gestures are concerned, it should be noted that the practice of taqsìr, the non-observance of Ramadan fasting and the non-construction of mosques were responses not to the secularizing efforts of the liberation movement but rather to participation in a society in which the religious (Muslim) element was important. From a desacralized historical perspective (Goikolea forthcoming), appealing to these practices should not be seen as "liberation from the weight of religion" but as an effort that can only be achieved in a situation of liminality, such as the total war in which the camps were situated - an effort that links nation-building to an egalitarian program that would be tested in part in the camps but that would not prefigure the state entirely. In the long stay in the camps, there were different moments of encouragement, which necessitated the adaptation of certain practices to maintain it.

\section{Taqsīr After 1991}

All of the interviewees referred to the end of the 1970s as a boom for taqsīr, after which its practice declined. Very few practice it today. No one could confirm the exact date, but it seems that in the late 1980s, the pressure to shorten prayers was relaxed. This occurred in a context marked by the demonstrations of 1988, which demanded the broadening of participation in state structures. This process 
was followed by a ceasefire with Morocco signed in 1991, which initially should have led to a referendum on self-determination and the possible dismantling of the refugee camps. As a result of this ceasefire, the men who returned to the refugee camps demobilized. Their reincorporation into civilian life coincided with frustration about the continued failure of negotiations with Morocco. In 2001, because of the route of the Paris-Dakar rally, the Polisario Front once again mobilized the population, threatening to return to battle. This threat was not successful, however, resulting in the 2004 Baker II plan and leaving the situation in a stalemate (Gomez and Omet 2009).

A new constitution for the SADR was approved in 1991. This constitution was meant to respond to the demand for political opening. This process was consolidated in subsequent constitutional and political changes. Because of this, the collective practices that had dominated the organizational and productive structure of the camps until then were collapsing. At some point in time, the expectation of independence and the demobilization of former fighters meant that the Polisario Front could no longer act as a vanguard, and thus institutional checks and balances were established and rights and freedoms guaranteed (Lippert 1992, 644). In this way, since the early nineties, different revolutionary practices linked to democratic centralism have been left behind.

Towards the 2000s, the changes became more evident, with a greater amount of cash moving through the camps. This phenomenon was accompanied by the reorganization of economic routes that crossed the Sahara and beyond. The refugee camps were situated in a strategic location, a hyperconnected point between Morocco, Mali, Algeria and Mauritania (Isidoros 2018). Where there had previously only been one store, the area was soon home to many markets. This began to generate evident inequalities, including with regards to forms of habitation. People no longer lived in tents but in houses, some of which had several rooms. In order to participate in these routes, solidarity networks that appealed to the connections of the $q a b \bar{a}$ 'il were involved. Although those links were supposed to have been erased by the revolution, they survived in the background, again like faint traces of text in a palimpsest (Wilson 2016). The emergence of these practices occurred not only at the social but also at the institutional level. During the Polisario Front's tenth congress, a Consultative Council of Shuyūkh was added to the legislative power. These represented the different qaba'il in the refugee camps. The appeal to these elders began when, during the events of the 1980s, consensus on the permanence of the camps seemed to be breaking. At the time, the cohesion and negotiation mechanisms characteristic of the qabā'il functioned as an agglutinating element (García 2001). Despite this, the state attempted to short-circuit the effects of tribal adscription (Wilson 2010).

In many interviews, we were told different versions of an anecdote in which President Mohammed Abdelaziz was annoyed that someone had been arrested for performing full prayers. He replied by saying that the important thing was to pray. ${ }^{35}$ In none of the interviews did they give us an exact date. In addition, some interviewees indicated that people were slowly moving away from full prayers. In the context of the stories, it seems that this phenomenon occurred between the end of the 1980s and the beginning of the 1990s. Contrary to the promulgation of the taqsirr, the return to full prayers did not come from a congress. Moreover, in 2004, in the wilāyah of Ausserd, the Ministry of Justice and Religious Affairs held a meeting to discuss a series of religious polemics that were considered relevant to life in the camps and among which 
the taqsīr was not present. This meeting was not carried out under the principle of democratic centralism but was instead an attempt to bring together positions on a series of debates. Finally, in terms of the participation of regional religious authority networks, ${ }^{36}$ in three interviews we were told that the Mauritanian faqīh Buddah uld Busairi was consulted in Nouakchott about the relevance of this practice in refugee camps. ${ }^{37}$

The political organization of religious authority changed in parallel to state institutions. Leaving democratic centralism aside, the organization of religious decisions turned to a logic that did not imply full agreement with regard to its decisions. The organization of religious authority in the bidān space was characterized by decentralized competition between individuals who sought to attract legitimacy. In this context, a community governed by dissent was created among influential individuals. By forcing agreement, democratic centralism had produced friction. With this said, the capacity of this dissent to bring about aggregation must also be taken into account. The return to this pre-revolutionary practice took place in a new context in which the dissenting community was the national one. The authority of the Mauritanian faqih was respected, but he was asked about the community structure of those living in the refugee camps. In the debate of 2004, dissent was respected, but it took place within the scope of the Ministry of Justice and Religious Affairs of the SADR, the state entity of the Sahrawi nation.

Changes in recent years may seem to indicate a significant degree of demobilization. Careful analysis of these changes, however, can help us to understand the ways in which these revolutionary initiatives remain present in everyday life (Wilson 2018, 188). Just as the figure of the munadila appeals to these liminal moments, those who practice shortened prayer create a link to this project. In this sense, the practice of taqsīr refers to the figure of resistance. Whenever this debate arose in everyday life, those who shortened their prayers were viewed as especially hard-working, usually older, people. This is an important element to consider: taqsīr is also linked to the life experiences of individuals. For those young people who grew up in the cities of El Aaiun and Tan-Tan, the shortened prayer allowed them to take up a necessary war effort with the aim of resettling in their homeland. However, most of those currently in refugee camps have never been in the part of Western Sahara that is occupied by Morocco. There is pressure to return because of Moroccan efforts to attract those who leave the camps (Boulay 2016). In this context, the practice of full prayer, which implies permanence, can be seen as a form of resistance, a way of maintaining liminality.

\section{Conclusion}

Following the historian Frederick Cooper (2005), it is necessary to take a historical perspective to avoid determinism and essentialism. In this sense, we must take into account the contexts in which each generation has emerged, in a conflict that has lasted more than forty years. Whereas in 1975 50\% of the population under examination was born in an urban environment, in 2004 most of the population was born in the camps. The experiences of many of the young people who carried out the revolution and the organization during the first years in the refugee camps was marked by their having grown up in cities such as El Aaiun, Tan Tan or Zuerat. For them, the camps were a temporary detour on the way back to their

\footnotetext{
$36 \quad$ More information on these networks in (Lydon 2009).

37 Interviewees 27, 29 and 43. In each interview we were given a date, however, and the interpretation of the conclusions given by Busari differ among the different versions.
} 
national homeland. The young people of today view the camps as forming their life experience and the practices in the camps as necessarily responding to these experiences. These different contexts can help us to understand the different problems that have arisen over time.

There is continuity, however, in what Alice Wilson $(2016,240)$ calls the moral contract that governs the camps. In cases of conflict, both refugees and the state-movement ${ }^{38}$ give priority to national liberation, which underpinned the Sahrawi refugees' revolution, over alternative interests such as personal material advancement or the interests of a particular family or tribe. In this sense, discrepancies concerning the political organization of religious authority can be understood as differences about political organization, not the community over which that authority is exercised.

Decisions regarding taqsīr were important because they were performed on a daily basis and affected intimate spheres of life. However, taqsīr's political significance was related to a situation of war and the need to mobilize society at a liminal moment. Over time, this impetus was relaxed, leaving a new society that differed from that which existed before the revolution and that imagined in the political programs of the 1970s. The return to the practice of full prayer is an example of this, a practice that can be interpreted as a return to normalcy but also as having new political significance in a context marked by resistance.

In this sense, much has been written about the institutional construction of its political legitimacy: the construction of a state in exile, of diplomatic representations, of governance structures, etc. It is worth reflecting on the corporality of this effort, however. Following the work of anthropologist Talal Asad (2003) on the secular, the Polisario Front's interest in defining this practice in a national context can be better understood. Doing so builds a political medium that "redefines and transcends particular and differentiating practices of the self that are articulated through class, gender, and religion” (5). In the sahrawi case, uniformization brought the national community together by eliminating status differences in a practice that maintained liminal tension - an exercise that, despite having to adapt to new contexts, seems to have succeeded.

\section{Declaration of Interest Statement}

The author declares no conflict of interest.

\section{References}

Allan, Joanna. 2019. Silenced Resistance: Women, Dictatorships, and Genderwashing in Western Sahara and Equatorial Guinea. Madison: The University of Wisconsin Press.

Allan, Joanna. 2010. “Imagining Saharari Women: The Question of Gender in Polisario Discourse.” The Journal of North African Studies 15 (2): 189-202.

Asad, Talal. 2003. Formations of the Secular: Christianity, Islam, Modernity. Stanford: Stanford University Press.

Bárbulo, Tomás. 2002. La historia prohibida del Sáhara Español: Las claves del conflicto que condiciona las relaciones entre España y el Magreb. Barcelona: Península. 
Barona, Claudia. 2009. Los hijos de las nubes, estructura y visicitudes del Sáhara Español desde 1958 hasta la debacle. Langre: Madrid.

Bengochea Tirado, Enrique and Francesco Correale. Forthcoming. "Modernising Violence and Social Change in the Spanish Sahara (1957-1975).” Itinerario.

Bennoune, Mahfuz. 1978. “The Political Economy of Mauritania: Imperialism and Class Struggle.” Review of African Political Economy 5 (12): 31-52.

Bonte, Pierre. 2017. Identités et changement socioculturel dans l'Ouest saharien (Sahara occidental, Mauritanie, Maroc). Khartala: Paris.

Bonte, Pierre. 1982. “Tribus, factions et État: Les conflits de succession dans l'émirat de l'Adrar.” In Cahiers d'études africaines 22 (87-88): 489-516. doi: 10.3406/cea.1982.3390.

Bonte, Pierre. 1979. “Segmentarité et pouvoir chez les éleveurs nomades sahariens.” In Équipe écologie et anthropologie des sociétés pastorales, ed., Pastoral Production and Society. Proceedings of the International Meeting on Nomadic Pastoralism, Paris, 1-3 Dec. 1976. Cambridge-New York: Cambridge University Press / Paris, Éd. de la MsH: 171-199.

Bonte, Pierre; Conte, Édouard and Dresch, Paul. 2001. Émirs et presidents: Figures de la parenté et du politique dans le monde arabe. Paris: CNRS Editions.

Boulay, Sébastien. 2016. “'Returnees’ and Political Poetry in Western Sahara: Defamation, Deterrence and Mobilisation on the Web and Mobile Phones." The Journal of North African Studies 21 (4): 667-686. doi: 10.1080/13629387.2016.1185942.

Brenner, Suzanne. 1996. "Reconstructing Self and Society: Javanese Muslim Women and 'The Veil'." American Ethnologist, no. 23: 673-97.

Caratini, Sophie. 2003. La République des sables: Anthropologie d'une Révolution. L’Harmattan: Paris.

Caratini, Sophie. 2000. “Système de parenté sahraoui, l’impact de la révolution.” L'Homme, no. 154-155: 431-456.

Caratini, Sophie. 1989. Les Rgaybāt (1610-1934). L’Harmattan: Paris.

Caro Baroja, Julio. 1954. Estudios Saharianos. ONO: Madrid.

Charre, Jean-Pierre. 1966. “Les Reguibat L’Gouacem: Système juridique et social.” Revue de géographie alpine 54 (2): 343-350.

Cooper, Frederick. 2005. Colonialism in Question: Theory, Knowledge, History. Berkeley: University of California Press.

Correale, Francesco and López Bargados, Alberto. 2017. "Rashomôn au Sahara Occidental: Perspectives, contradictions et défis dans l'interpretation d'un conflit de 1956-1958." In Culture et politique dans l'Ouest Saharien. Arts, activisme et État dans un espace de conflits, edited by Sébastien Boulay and Francisco Freire, 211-242. L’Étrave: Igé.

Diego Aguirre, Jose Ramón. 1988. “La lucha del frente polisario: 1973-75.” Historia 16 (151): 12-22.

Eisenstadt, Shmuel. 2000. “Multiple Modernities.” Daedalus 129 (1): 1-29.

Ennaji, Mohammed. 2013. Slavery, the State, and Islam. Cambridge: Cambridge University Press.

Fiddian-Qasmiyeh, Elena. 2014. The Ideal Refugees: Gender, Islam, and the Sahrawi Politics of Survival. Syracuse: Syracuse University Press.

Fiddian-Qasmiyeh, Elena. 2011. “The Pragmatics of Performance: Putting 'Faith' in Aid in the Sahrawi Refugee Camps.” Journal of Refugee Studies 2 (3): 533-547.

Freire, Francisco. 2017. "The Hemeila Riddle: Genealogical Reconfigurations of Pre-colonial Encounters in Southwestern Mauritania.” History and Anthropology 28 (2): 149-165.

García, Alejandro. 2001. Historias del Sahara, lo mejor y lo peor de los mundos. Madrid: La Catarata.

Gellner, Ernest. 1983. Nations and Nationalism. Ithaca: Cornell University Press. 
Gellner, Ernest. 1981. Muslim Society. Cambridge: Cambridge University Press.

Gennep, Arnold van. 1960. The Rites of Passage. Chicago: University of Chicago Press.

Gimeno Martin, Juan Carlos. 2007. Transformaciones socioculturales de un proyecto revolucionario: la lucha del pueblo Saharaui por la liberación. Caracas: Programa Cultura, Comunicación y Transformaciones Sociales.

Goikolea, Itzea. Forthcoming. "Historizar para decolonizar.” Ayer.

Gómez Martín, Carmen and Omet, Cédric. 2009. "Les ‘dissidences non dissidentes’ du Front Polisario dans les camps de réfugiés et la diaspora sahraouis.” L’Année du Maghreb, no. 5: 205-222.

Isidoros, Konstantina. 2018. Nomads and Nation-Building in the Western Sahara: Gender, Politics and the Sahrawi. London: IB Tauris.

Isidoros, Konstantina. 2016. "Unveiling the Colonial Gaze: Sahrāwī Women in Nascent Nation-State Formation in the Western Sahara.” Interventions: International Journal of Postcolonial Studies 19 (4): 487506.

Isidoros, Konstantina. 2015. "The Silencing of Unifying Tribes: The Colonial Construction of Tribe and Its 'Extraordinary Leap' to Nascent Nation-State Formation in Western Sahara.” Journal of the Anthropological Society of Oxford 7 (2): 168-190.

Laman, Mohammed Ali. 2009. al-șaḥrā’ algharbīa: mukhtami 'ah ua zaqāfa. Rabuni: Infosolidarité.

Lippert, Anne. 1992. "Sahrawi Women in the Liberation Struggle of the Sahrawi People." Signs 17 (3): 636-651.

López Bargados, Alberto. 2003. Arenas coloniales: Los Awlad Dalim ante la colonización franco-española del Sáhara. Barcelona: Ediciones Bellaterra.

Lydon, Ghislaine. 2009. On Trans-Saharan Trails: Islamic Law, Trade Networks, and Cross-Cultural Exchange in Nineteenth Century Western Africa. New York: Cambridge University Press.

Medina Martin, Rocío. 2014. "Mujeres Saharauis, Colonialidad del Género y Nacionalismos: un acercamiento a partir de los feminismos decoloniales.” Relaciones Internacionales, no 27: 13-34.

Mercer, John. 1979. The Sahrawis of Western Sahara. London: Minority Rights Group Report.

Mundy, Jacob. 2007. "Performing the Nation, Prefiguring the State: The Western Saharan Refugees Thirty Years Later.” Journal of Modern African Studies 45 (2): 275-297.

Norris, Harry Thirwal. 1964. "The Wind of Change in the Western Sahara." The Geographical Journal 130(1): 1-14.

Ould al-Bara, Yahia. 2000. "Le milieu culturel et social des fuqahā maures.” In Élites du monde nomade touareg et maure, edited by Pierre Bonte and Hélène Claudot-Hawad. Aix-en-Provence: Institut de recherches et d'études sur les mondes arabes et musulmans. doi:10.4000/books.iremam.2669.

Pazzanita, Anthony. 2006. Historical Dictionary of Western Sahara. Lanham: Scarecrow Press

Rappaport, Joanne. 2008. "Beyond Participant Observation: Collaborative Ethnography as Theoretical Innovation.” Collaborative Anthropologies 1: 1-31. doi:10.1353/cla.0.0014.

Rivoal, Isabelle, and Salazar, Noel. 2013. "Contemporary Ethnographic Practice and the Value of Serendipity.” Social Anthropology 21 (2): 178-185.

Salvatore, Armando. 2007. The Public Sphere: Liberal Modernity, Catholicism, Islam. New York: Palgrave Macmillan.

San Martin, Pablo. 2010. Western Sahara: The Refugee Nation. Cardiff: University of Wales Press.

Solana, Vivian. 2017. "Cementing Nationalism: The Role of the Saharawi Female Revolutionary in Her Struggle for Decolonization.” In Culture et politique dans l'Ouest Saharien: Arts, activisme et État dans un espace de conflits, edited by Sébastien Boulay and Francisco Freire, 423-444. Igé: L’Étrave. 
Tarrow, Sidney. 2011. Power in Movement: Social Movements and Contentious Politics. Cambridge: Cambridge University Press.

Turner, Victor. 1969. The Ritual Process: Structure and Anti-Structure. London: Routledge.

Wilson, Alice. 2018. "Poursuivre la révolution: une perspective depuis les camps de réfugiés sahraouis.” In Sahara Occidental: Conflit oublié, population en mouvement, edited by Sébastien Boulay and Francesco Correale, 177-191. Tours: François Ravelais.

Wilson, Alice. 2016. Sovereignty in Exile: A Saharan Liberation Movement Governs. Philadelphia: University of Pennsylvania Press.

Wilson, Alice. 2010. "Democratising Elections without Parties: Reflections on the Case of the Saharawi Arab Democratic Republic.” The Journal of North African Studies 15 (4): 423-438.

Wilson, Alice, and Fiona McConnell. 2015. "Constructing Legitimacy without Legality in Long Term Exile: Comparing Western Sahara and Tibet.” Geoforum, no. 66: 203-214.

Ware III, Rudolph. 2014. The Walking Qur'an: Islamic Education, Embodied Knowledge, and History in West Africa. Chapel Hill: The University of North Carolina Press. 